\title{
ASPEK-ASPEK HUKUM PERJANJIAN DISTRIBUTOR DAN KEAGENAN \\ (SUATU ANALISIS KEPERDATAAN)
}

\author{
Ari Wahyudi Hertanto'
}

\begin{abstract}
Abstrak
Distributor is formed on individual, partnership, company, association or another legal which have standing position between producer and retailers. They have roles on purchasing, delivering or contracts of sale toward consumption goods. Under Indonesian Civil Code system that contract is categorized as innominat contract by that kind that has not been regulated under the system. But also under principal of Civil Code it might to be signed under restrictions has not by act, sealed by not violence public order and ethics. By respect through those principles then any signed contract become effective as act for signed parties. The author here also indicates on practice trends of applying standard contract that printed forms collectively. In practice it still giving any freedom beside that standard contract and for the distributor's respect and bound himself to the whole of contract's structure.
\end{abstract}

Kata kunci: hukum keperdataan, analisis, perjanjian, distributor dan keagenan

\section{Pendahuluan}

Lembaga distributor dalam prakteknya bukan merupakan suatu hal yang baru. Namun demikian, seiring dengan berkembangnya praktek-praktek dunia usaha baik dalam skala domestik maupun internasional, sedikit banyak memberikan suatu pengaruh terhadap bagaimana lembaga distributor dimaksud dalam menjalankan praktek usahanya. Tidak jarang lembaga usahanya adalah distributor tetapi justru pada prakteknya merupakan lembaga sub-distributor atau bahkan pada prakteknya lembaga-lembaga distributor ini melakukan praktek-praktek layaknya retailer (pedagang

${ }^{1}$ Penulis adalah pengajar Mata Kuliah Ilmu Negara dan Mata Kuliah Pancasila pada Fakultas Hukum Universitas Indonesia dan pengajar Mata Kuliah-Mata Kuliah Ilmu Negara. Hukum Perusahaan. Pendidikan Pancasila dan Kewarganegaraan dan Hukum Perdata pada Fakultas Hukum Universitas Al Azhar Indonesia. 
eceran). Secara umum memang para pelaku usaha yang kreatif adalah mereka-mereka yang dapat mempertahankan kinerja usaha perusahaannya untuk kurun waktu yang lama. Eksistensi lembaga ini ada karena tuntutan ekonomi yang kerangkanya adalah bagaimana mempercepat produk-produk dapat sampai ke tangan para penggunanya.

Faktor kelangsungan usaha merupakan kunci penting dari sebuah perusahaan. Sedangkan, bagaimana untuk menciptakan kelangsungan usaha tersebut juga merupakan hal lain yang terintegrasi dengan kreatifitas untuk memenuhi keinginan pasar. Sudah merupakan suatu tolok ukur sederhana bahwa tidak ada pasar yang memiliki loyalitas mutlak terhadap suatu produk dan jasa, melainkan bagaimana produk dan jasa dapat memenuhi kepuasan pasar dengan berbagai insentif yang diberikan yang oleh karenanya akan diburu oleh pasar. Sifat pasar yang sedemikian rupa menjadikan para pedagang besar ataupun para distributor dituntut untuk senantiasa kreatif dalam mempertahankan bisnisnya.

Sebelum membahas lebih jauh tentang lembaga distributor ini, maka penulis akan terlebih dahulu melakukan pembahasan dalam tatanan teoritis dan konstruksi normatif yuridis dari sebuah lembaga distributor, dimana didalamnya turut disinggung sedikit tentang korelasinya dengan lembaga keagenan. Secara umum kita mengenal dua jenis pembantu perusahaan, yaitu pembantu-pembantu dalam perusahaan dan pembantu-pembantu di luar perusahaan. Pembantu-pembantu dalam perusahaan itu antara lain adalah:

1. Pengurus filial (fillaalhoulder) ialah petugas yang mewakili pengusaha mengenai semua hal, tetapi terbatas pada satu cabang perusahaan atau satu daerah tertentu, misalnya: pimpinan pusat perusahaan berada di Jakarta, sedangkan cabang perusahaan itu ada di Semarang, Surabaya, Yogyakarta, Bandung, Medan dan Makasar. Pada cabang-cabang ini ada pengurus filial-nya yang mengemudikan perusahaan, terbatas posa łaerah/wewenang cabang itu;

2. Pemegang prokurasi (procuratiehoulder) ialah pemegang kuasa dari perusahaan. Dia adalah wakil pimpinan perusahaan atau wakil manager, dan dapat mempunyai kedudukan sebagai kepala satu bagian besar dari perusahaan itu. Dia adalah orang kedua sesudah manager (pimpinan perusahaan); dan

3. Pimpinan perusahaan (manager, bedrijfsleider) adalah pemegang kuasa pertama dari pengusaha perusahaan. Dia adalah yang mengemudikan seluruh perusahaan. Dialah yang bertanggung jawab atas maju dan mundurnya perusahaan. Dalam istilah 
sekarang dia adalah direktur utama, sedangkan di bawahnya adalah direktur-direktur. ${ }^{2}$

Khusus membahas teritang direktur sebagaimana yang dipaparkan pada angka 3 tersebut di atas, yaitu orang yang diberi wewenang untuk memegang salah satu bidang perusahaan tertentu. Direktur inilah pemegang prokurasi. Selain itu, kita juga mengenal pembantu-pembantu di luar perusahaan, antara lain:

1. Agen perusahaan adalah orang yang melayani beberapa pengusaha sebagai perantara dengan pihak ketiga;

2. Makelar, menurut pengertian undang-undang, seorang makelar pada pokoknya adalah seorang perantara yang menghubungkan pengusaha dengan pihak ketiga untuk mengadakan pelbagai perjanjian, mengenai makelar ini diatur dalam Kitab UndangUndang Hukum Dagang ("KUHD"), Buku I Pasal 62 sampai dengan Pasal 72, dan menurut Pasal 62 ayat 1 makelar mendapat upahnya yang disebut provisi atau courtage; dan

3. Komisioner adalah orang yang menjalankan perusahaan dengan membuat perjanjian-perjanjian atas namanya sendiri, mendapat provisi atas perintah dan atas pembiayaan orang lain, mengenai komisioner itu diatur dalam Bab V, Bagian I, Pasal 76 sampai dengan Pasal 85a, Buku I KUHD.

Sehubungan dengan adanya konstruksi bisnis tersebut di atas dan dengan adanya perkembangan di dunia perdagangan, maka bidang hukum perikatan pun mengalami pertumbuhan. Namun, ketentuan-ketentuan yang terdapat pada KUHD banyak yang kurang dapat mencakup perkembangan bisnis masa kini. Salah satu di antaranya adalah mengenai perjanjian keagenan dan kedistributoran. ${ }^{4}$ Sementara itu lembaga keagenan maupun distributor juga hidup dan berkembang secara dinamis, serta oleh karenanya formulasi perjanjian baku dimaksud pun terus mengalami perubahan seiring dengan berkembangnya pasar. 1995). hal. 43.

2H.M.N. Purwosutjipto. "Pengertian Pokok Hukum Dagang I". (Jakarta: Djambatan

\section{lbid. hal. 43}

'Felix Oentoeng Soebagjo. "Beberapa Aspek Hukum Dari Perjanjian Keagenan Dan Distributor". Majalah Hukam dan Pembangunam, Tahun ke-27 No. 3 Juli-September 1997. (Jakarta: Fakultas Hukum Universitas Indonesia). 
Khusus tentang distributor sesuai dengan ketentuan pada Pasal 1319 Kitab Undang-Undang Hukum Perdata ("KUHPer"). distributor dapat dikategorikan dalam ketentuan-ketentuan mengenai perjanjian tidak bernama (innominaat). Dalam KUHPer mempunyai beberapa ketentuan yang mengatur tentang perjanjian-perjanjian bernama yang dinyatakan dalam Pasal 1338 KUHPerdata bahwa:

"Semua perikatan yang dibuat sesuai dengan undang-undang maka berlaku sebagai undang-undang bagi mereka yang membuatnya."

Perikatan yang sesuai dengan undang-undang itu diantaranya, adalah: ${ }^{5}$

1. Jual beli menurut Burgerlijk Wetboek ("BW") adalah suatu perjanjian bertimbal balik dalam mana pihak yang satu (si penjual) berjanji untuk menyerahkan hak milik atas suatu barang, sedang pihak yang lainnya (si pembeli) berjanji untuk membayar harga yang terdiri atas sejumlah uang sebagai imbalan dari perolehan hak milik tersebut (Pasal 1457-1540 BW);

2. Tukar menukar adalah suatu perjanjian dengan aman kedua belah pihak mengikatkan dirinya untuk saling memberikan suatu barang secara bertimbal-balik sebagai gantinya suatu barang lain Pasal 1541-1546 BW;

3. Sewa menyewa adalah suatu perjanjian dengan mana pihak yang satu mengikatkan dirinya untuk memberikan kepada pihak yang lainnya kenikmatan dari sesuatu barang, selama suatu waktu tertentu dan dengan pembayaran suatu harga yang oleh pihak yang tersebut terakhir itu disanggupi pembayarannya (Pasal 1547-1600 BW); dan

4. Persetujuan-persetujuan untuk melakukan pekerjaan (Pasal 1601$1617 \mathrm{BW})$.

Distributor dalam dunia perdagangan mempunyai peranan yang hampir sama dengan lembaga keagenan yaitu sebagai perantara untuk memudahkan penyampaian barang dari produsen ke konsumen. Namun demikian pada kurun waktu sebelum tahun 1990 distributor cenderung kurang diperhatikan perkembangannya dari segi hukum, hal ini berbeda dengan lembaga keagenan yang oleh pemerintah Republik Indonesia dalam hal ini melalui Departemen Perdagangan dan Perindustrian, telah 
dikembangkan sedemikian rupa dalam bentuk lembaga pengakuan agen tunggal, dimana disyaratkan bagi perusahaan asing yang akan memasarkan barang-barang produksinya di Indonesia, harus menunjuk satu perusahaan nasional yang akan merupakan agen tunggalnya, dan sekaligus sebagai pemegang merek (agen tunggal pemegang merek) dari barang-barang tersebut.

Secara khusus Ketentuan perundang-undangan yang mengatur tentang distributor belum ada, jadi ketentuan-ketentuan yang berlaku adalah ketentuan-ketentuan yang dikeluarkan oleh beberapa departemen teknis misalnya, Departemen Perdagangan dan Perindustrian yang diatur dalam Surat Keputusan Menteri Perdagangan Nomor 77/Kp/III/78, tanggal 9 Maret 1978 yang menentukan bahwa lamanya perjanjian harus dilakukan. Sampai dengan dikeluarkannya Keputusan Menteri Perindustrian dan Perdagangan No.23/MPP/KEP/1/1998 tentang Lembaga-Lembaga Usaha Perdagangan (Kepmen No.23/1998) sebagaimana kemudian diubah dengan dikeluarkannya Keputusan Meteri No.159/MPP/Kep/4/1998 tentang Perubahan Keputusan Menteri Perindustrian dan Perdagangan No.23/MPP/Kep/1/1998 tentang Lembaga-Lembaga Perdagangan. Selain itu para pihak dalam membuat perjanjian keagenan dan/atau distributor biasanya mendasarkan pada asas kebebasan berkontrak sebagaimana yang dianut oleh Pasal 1338 KUHPerdata.

Seharusnya dengan adanya asas kebebasan berkontrak tersebut, posisi kedua belah pihak adalah sama dan sederajat. Namun, dalam praktek sebenarnya kedua pihak tidak dalam posisi yang seimbang. Seringkali terjadi pihak distributor harus menerima persyaratan-persyaratan yang diberikan oleh perusahaan produsen secara mutlak tanpa bisa menawar lagi. Hal ini disebabkan perusahaan prinsipal telah mempersiapkan standar formulirformulir kontrak, berarti bagi distributor yang ingin mengadakan perjanjian dengan pihak produsen terikat dengan formulir-formulir kontrak yang sudah disediakan pihak produsen. Adapun hal yang melatarbelakangi dibuatnya suatu standar kontrak adalah untuk mempermudah perusahaan prinsipal dalam menjalankan usahanya, yang dalam lingkup usahanya perusahaan prinsipal telah mempersiapkan jaringan distribusi produknya tidak secara ekslusif dipegang oleh 1 (satu) distributor dan hanya pada 1 (satu) negara, melainkan lebih dari itu. Oleh karenanya untuk mempermudah aspek pemahaman transaksi. pola administrasi dan permasalahan lainnya, maka perusahaan prinsipal cenderung menjalankan pola pemberlakuan standar kontrak baku tersebut.

Sebagai penyalur barang dan jasa dalam sistem perdagangan, distributor memiliki berbagai macam hubungan kerja dengan berbagai pihak, terutama dengan mitra kerja utamanya, pengecer (retailer) dan khususnya 
produsen. Jika pengecer-pengecer dapat dimasukkan pula sebagai distributor, maka kedudukan distributor berada di tengah-tengah antara produsen dan konsumen. Tetapi secara umum, distributor cenderung senantiasa dikaitkan dengan konsep wholesaler (pedagang besar), karena itu, tidak berhubungan dengan konsumen secara langsung. ${ }^{6}$

Kendati terdapat perbedaan konsep, terkandung ciri menonjol dalam diri ditributor, yakni perannya sebagai "pintu keluar" barang dan jasa menuju konsumen. Karakter ini menyebabkan ia mempunyai hubungan hukum yang sangat dekat dengan penghasil barang (fabricant). Pola hubungan hukum ini dapat berupa pemberian kuasa sebagaimana yang diatur dalam Pasal 1792 KUHP dan seterusnya, seperti pada sole distributor (distributor tunggal), atau pola-pola lain yang sepenuhnya bebas dari ikatan hubungan yang bersifat agency yang menumbuhkan hubungan hukum yang bersifat sub-ordinate (adanya hubungan hukum atas-bawah). Pedagang-pedagang besar farmasi (PBF) dan pusat-pusat grosir (perkulakan) tertentu lebih condong memilih pada bentuk terakhir tersebut.

\section{Tinjauan Umum Distributor Dan Agen}

\section{Pengertian Lembaga Distributor dan Agen}

Lembaga distributor ini adalah salah satu lembaga dalam perjanjian Keagenan. Lembaga distributor ini terjadi apabila dalam suatu perjanjian antara agen tunggal itu tidak merangkap sebagai distributor, dan sebagai agen tunggal suatu perusahaan dapat menunjuk suatu perusahaan lain sebagai distributor bagi barang-barang yang di datangkan oleh agen tunggal.

Beberapa definisi yang diberikan terhadap terminologi distributor antara lain adalah:

a. Alan Giplin?

Distributor is who has been granted by a company, an exclusive or prefertial right to buy and sell a specific range of its good or service in specified markets.

b. Dalam Dictionary of Business and Economic.

'P. Susilo. "Prinsip-prinsip Praktis Perlindungan Distributor". (Jakarta: 2002), hal.

${ }^{7}$ Alan Giplin. "Dictionary Of Teras". (London: ButterWorth \& Co. 1977). 


\section{Distributor is an individual of firm selling munufactured products}

c. Distributor is any individual, partnership, corporation, association or other legal relationship which stands between the manufacturer and retail seller in purchases. consignments, or contract for sale of consumen goods. A wholesaler jobber or other merchant middlemen authorized by a manufacturer or supplier to sell chiefly to retailers and commercial users ${ }^{8}$.

Kebutuhan akan adanya perusahaan yang dapat menjadi perantara guna memperluas jaringan pemasaran barang-barang dan jasa dari produsen ke konsumen menyebabkan adanya perusahaan keagenan di Indonesia. Sementara itu dalam sistem hukum Indonesia, terutama dalam hukum perdata dan hukum dagang tidak ditemukan ketentuan tentang keagenan. Sudah barang tentu dengan tingkat populasi kepadatan penduduk yang sedemikian banyak merupakan potensi pasar yang luar biasa. Negara-negara produsen sudah barang tentu memiliki kepentingan tersendiri agar supaya produk-produk mereka dapat terjual di pasaran.

Pemerintah menyikapi perkembangan dalam dunia usaha dan oleh karenanya dalam rangka berusaha untuk membina dan mengembangkan industri, dalam perkembangannya terdapat beberapa ketentuan pelaksanaan yang mengatur tentang keagenan telah dikeluarkan yang antara lain adalah Keputusan Menteri Perindustrian dan Perdagangan No.23/MPP/KEP/1/1998 tentang Lembaga-Lembaga Usaha Perdagangan (Kepmen No.23/1998) sebagaimana kemudian diubah dengan dikeluarkannya Keputusan Menteri No.159/MPP/Kep/4/1998 tentang Perubahan Keputusan Menteri Perindustrian dan Perdagangan No.23/MPP/Kep/1/1998 tentang Lembaga-Lembaga Perdagangan.

Sebagaimana disampaikan dalam Laporan Pengkajian tentang Beberapa Aspek Hukum Perjanjian Keagenan dan Distribusi yang disusun oleh Badan Pembinaan Hukum Nasional Departemen Kehakiman tahun 1992/1993 berikut adalah hasil penelitiannya, dimana agen dalam melakukan perbuatan hukum

"Henry Campbell Black MA. "Black's Law Dictionary". Abridged Sixth Edition. reprint-1998. (U.S. West Publishing Company, 1979). hal. 427. 
dengan pihak ketiga, kedudukannya adalah merupakan kuasa prinsipal. Agen bukan karyawan prinsipal. Perbuatan-perbuatan hukum yang berkaitan dengan transaksi perdagangan yang harus dilakukan oleh agen untuk prinsipalnya diatur dalam perjanjian keagenan yang dibuat antara agen dan prinsipalnya. Biasanya agen diberi kuasa dan wewenang untuk melakukan penjualan dan promosi barang-barang prinsipal.

Sehubungan agen dalam kegiatannya bertindak mewakili prinsipalnya berdasarkan pemberian kuasa maka hubungan hukum antara agen dengan prinsipalnya, sifatnya, tidak seperti hubungan antara majikan dengan buruh. Dalam perjanjian perburuhan yang paling penting adalah penyediaan tenaga kerja semata-mata dengan memperoleh upah, disamping itu terdapat kedudukan buruh yang lebih rendah daripada majikan, dimana hal demikian itu tidak dijumpai pada hubungan antara agen dan prinsipal. Istilah prinsipal ini memberikan kesan seolah-olah pengusaha atau perusahaan di luar negeri adalah majikan atau atasan dari agen di Indonesia. Padahal sebenarnya agen (di Indonesia) bukanlah bawahan dari prinsipal itu. Padahal, sebenarnya agen dan prinsipal ada pada posisi yang setingkat.

Agen bertindak melakukan perbuatan hukum misalnya menjual barang atau jasa tidak atas namanya sendiri tetapi atas nama prinsipal. Agen dalam hal ini berkedudukan sebagai perantara. Jika agen mengadakan transaksi (negosiasi) dengan konsumen/pihak ketiga maka barang dikirimkan langsung dari prinsipal kepada konsumen. Pembayaran atas barang yang telah diterima oleh konsumen secara langsung kepada prinsipal bukan melalui agen, sedangkan pembayaran kepada agen berupa komisi dari hasil penjualannya. Hak-hak dan kewajiban para pihak dituangkan dalam perjanjian keagenan yang dibuat berdasarkan asas kebebasan berkontrak sehingga jika dilihat maka hubungan yang terjadi antara agen dengan prinsipalnya adalah tunduk kepada perjanjian pemberian kuasa sebagaiman diatur dalam ketentuan Pasal 1792 KUHPer.

Mengenai hubungan distributor dengan prinsipalnya untuk memasarkan dan menjual barang-barang prinsipal dalam wilayah dan jangka waktu tertentu berdasarkan kesepakatan bersama, distributor ditunjuk oleh prinsipal. Dalam keadaan ini, biasanya distributor bukan berkedudukan sebagai kuasa prinsipal tetapi bertindak untuk atas namanya sendiri (independent tracier). Distributor membeli sendiri barang-barang dari prinsipal tuntuk 
dijual kemudian. Sebagai akibat hukum dari perbuatan distributor, semuanya menjadi tanggung jawab distributor itu sendiri. Adapun hubungan hukum yang terjadi antara distributor dan prinsipalnya adalah tunduk pada perjanjian komisi.

Selanjutnya Kepmen No.23/1998 memberikan pengklasifikasian lembaga keagenan dan distributor sesuai dengan perkembangan dan praktek dilapangan yaitu menjadi sebagai berikut:

a. Agen tunggal pemegang merek (ATPM) termasuk agen pemegang lisensi perorangan atau badan usaha yang ditunjuk untuk dan atas nama pabrik pemilik merek barang tertentu untuk melakukan penjualan dalam partai besar barang dari pihak tersebut.

b. Agen, adalah perorangan atau badan usaha yang bertindak sebagai perantara untuk dan atas nama pihak yang menunjuknya untuk melakukan pembelian, penjualan/pemasaran tanpa melakukan pemindahan fisik barang.

c. Agen pabrik (manufactures agent), adalah agen yang melakukan kegiatan penjualan untuk dan atas nama kepentingan pabrik yang menunjuknya tanpa melakukan pemindahan fisik barang.

d. Agen penjualan (sales agent), adalah agen yang melakukan penjualan atas nama dan untuk kepentingan pihak lain yang menunjuknya tanpa melakukan pemindahan fisik barang.

e. Agen pembelian (purchasing agent), adalah agen yang melakukan pembelian atas nama dan untuk kepentingan pihak lain yang menunjuknya tanpa melakukan pemindahan fisik barang.

f. Agen penjualan pemegang merek (APPM), adalah agen yang melakukan penjualan atas nama dan untuk kepentingan agen tunggal pemegang merek (ATPM) yang menunjuknya.

g. Distributor utama (main distributor), adalah perorangan atau badan usaha yang bertindak atas namanya sendiri yang ditunjuk oleh pabrik atau pemasok untuk melakukan pembelian, penyimpanan. penjualan serta pemasaran barang dalam partai besar secara tidak langsung kepada konsumen akhir terhadap barang yang dimiliki/dikuasai oleh pihak lain yang menunjuknya.

h. Sub distributor, adalah perorangan atau badan usaha yang ditunjuk oleh distributor utama atau grosir yang bertindak 
atas namanya sendiri untuk melakukan kegiatan penjualan barang dalam partai besar sampai pada pengecer.

Selanjutnya dalam pasal 2 dan 3 Kepmen N0.23/1998 diadakan penggolongan atau pengkategorian pada Lembagalembaga Usaha Perdagangan, yaitu lembaga perdagangan yang termasuk sebagai Pedagang Besar dan Pedagang Pengecer (Retailer). Pada Pasal 2 menyebutkan bahwa yang termasuk sebagai Pedagang Besar adalah distributor utama, perkulakan (grosir), sub distributor, pemasok besar (main supplier). dealer besar, agen tunggal pemegang merek. Dimana terhadap para pedagang yang termasuk dalam kategori Pedagang Besar dimaksud harus memenuhi ketentuan sebagai berikut:

a. Menguasai gudang secukupnya sesuai dengan kebutuhan barang yang diperdagangkan.

b. Mempunyai jaminan sarana transportasi yang cukup.

c. Menerapkan manajemen modern dalam pengelolaan usahannya.

Selanjutnya turut ditentukan bahwa terhadap Pedagang Besar dilarang melakukan kegiatan sebagai pengecer dan pedagang informal.

Pada Pasal 3 Kepmen No 23/1998 ditegaskan bahwa yang termasuk sebagai Pedagang Pengecer (Retailer) adalah Agen Pabrik dan Agen Penjualan, Agen Pembelian, Agen Penjualan Pemegang Merk, Pemasok (Supplier), Dealer pengecer, dan Pengecer Tanpa Toko.

\section{Perbedaan antara Distributor dengan Agen}

Agen dan distributor sebenarnya merupakan dua terminologi yang berbeda dan mempunyai konotasi yang berbeda pula. Namun agen dan distributor mempunyai fungsi dan manfaat yang hampir sama yaitu memberikan jasa perantara dari prinsipal atau penunjuk kepada konsumen di wilayah pemasaran tertentu.

Jika diperhatikan lebih mendalam, maka akan terlihat perbedaan yang spesifik antara agen dan distributor, yaitu: ${ }^{9}$

Laporan Pengkajian tentang Beberapa Aspek Hukum Perjanjian Keagenan dan Distribusi yang disusun oleh Badan Pembinaan Hukum Nasional Departemen Kehakiman tahun 1992/1993. hal.10. 
a. Agen:

a. Pihak yang menjual barang atau jasa untuk dan atas nama prinsipal;

b. Pendapatan yang diterimanya berupa komisi berdasarkan jumlah barang atau jasa yang dijualnya kepada konsumen;

c. Barang dikirimkan langsung dari prinsipal ke konsumen jika antara agen dengan konsumen mencapai suatu persetujuan;

d. Pembayaran atas barang yang telah diterima konsumen langsung kepada prinsipal bukan melalui agen.

b. Distributor:

a. Perusahaan yang bertindak untuk dan atas namanya sendiri;

b. Membeli dari prinsipal dan menjual kembali kepada konsumen kepentingannya sendiri;

c. Prinsipal tidak selalu mengetahui konsumen akhir dari produk-produknya;

d. Bertanggung jawab atas keamanan pembayaran barang-barangnya untuk kepentingan sendiri.

\section{Terjadinya Lembaga Distributor}

Dalam rangka pelaksanaan dari penanaman modal dalam negeri yang tertera dalam Undang-Undang No. 6 Tahun 1968, pemerintah mengeluarkan peraturan pelaksana mengenai pengakhiran kegiatan usaha asing dalam bidang perdagangan yaitu : Peraturan Pemerintah No. 36/1977. Salah satu alternatif yang diberikan oleh Peraturan Pemerintah (PP) No. 36/1977 terhadap perusahaan asing seperti yang tercantum dalam Pasal 7 dari Peraturan Pemerintah tersebut adalah:

"Dapat menunjuk perusahaan nasional sebagai penyalur (Agen dan Distributor)."

Kebutuhan akan adanya lembaga yang dapat menjadi perantara guna memperluas jaringan pemasaran barang dan jasa dari produsen kepada konsumen menyebabkan lembaga distributor itu berkembang pesat di Indonesia. 
Di Indonesia, lembaga distributor merupakan salah satu dari sekian banyak lembaga perdagangan yang diatur secara khusus dalam Kepmen No.23/1998. Kepmen tersebut merupakan suatu upaya dalam rangka terciptanya suatu tertib niaga dan kelancaran distribusi barang dan jasa serta perlindungan konsumen didalam negeri, maka perlu dibuat keseragaman pengertian dan ruang lingkup kegiatan lembaga-lembaga perdagangan di dalam tata perdagangan dan distribusi nasional.

Perjanjian distributor secara khusus tidak dikenal dalam KUHPer dan KUHD. Sehingga perjanjian itu dapat digolongkan dalam perjanjian innominaat (perjanjian tidak bernama), serta keberadaannya dimungkinkan berdasarkan asas konsensualisme.

Berdasarkan asas konsensualisme, maka perjanjian yang akan dilakukan oleh distributor harus memenuhi syarat untuk sahnya suatu perjanjian seperti yang tercantum di dalam Pasal 1320 KUHPer. Dengan demikian secara tidak langsung berlaku Pasal 1338 ayat KUHPer yang menyatakan: "Semua perjanjian yang dibuat secara sah, maka berlaku sebagai Undang-Undang bagi mereka yang membuatnya".

Oleh karenanya pengangkatan dan penunjukan perusahaan oleh agen tunggal sebagai distributor itu wajib dilakukan dengan suatu yang eksklusif untuk jangka waktu tertentu sesuai dengan sifat dan tujuan penggunaan barang modal dan barang industri yang menjadi obyek dari suatu perjanjian.

Hal-hal yang harus dipenuhi oleh prinsipal dan distributor menyangkut pada pokok-pokok yang penting untuk dirumuskan dalam perjanjian dimaksud antara lain adalah menyangkut masalah-masalah sebagai berikut:

a. Nama dan Alamat lengkap dari para pihak yang membuat perjanjian.

b. Uraian dan rincian mengenai maksud dan tujuan dari dibuatnya perjanjian itu.

c. Uraian terperinci tentang barang-barang yang akan menjadi obyek perjanjian tersebut.

d. Sasaran yang hendak dicapai melalui pelaksanaan perjanjian, sesuai dengan keadaan dari waktu ke waktu.

e. ketentuan ketentuan tentang tata cara dan penerimaan pembayaran yang harus dipenuhi, terutama dengan memperhatikan bahwa perjanjian ini mencakup perjanjian yang bersifat trans-nasional maka tidak jarang diperlukan adanya suatu jaminan yang mendahului 
sebagai bukti kemampuan untuk membayar dari pihak yang ditunjuk sebagai distributor.

f. Ketentuan-ketentuan pokok yang disepakati bila karena suatu sebab, maka perjanjian itu dibatalkan.

g. Ketentuan-ketentuan pokok yang disepakati mengenai apa yang dinamakan kegiatan yang sangat tidak wajar atau tidak memuaskan dalam pelaksanaan perjanjian.

\section{Dasar Hukum Perjanjian Distributor}

Perjanjian merupakan dasar dalam melaksanakan perjanjian distributor, karena dalam perjanjian diatur hak dan kewajiban dari para pihak.

Perjanjian distributor termasuk dalam perjanjian innominat (tak bernama), karena tidak diatur secara khusus dalam KUHPer. Sekalipun tidak diatur secara khusus, tetapi tetap harus tunduk pada peraturan atau ketentuan umum Buku III KUHPer.

Dasar hukum dari perjanjian distributor adalah asas dari Buku III yang memberikan kebebasan berkontrak dan sifatnya yang terbuka yang memungkinkan masyarakat dapat membuat segala macam perjanjian di luar perjanjian-perjanjian yang terdapat dalam KUHPer Buku III, yaitu:

a. Sifat terbuka dari Buku III KUHPer memungkinkan setiap individu dalam masyarakat untuk bebas membuat segala macam perjanjian, baik yang terdapat dalam Buku III,maupun yang terdapat di luar buku III. Macam dari perjanjian tersebut harus tunduk pada ketentuanketentuan Umum Perjanjian (Pasal 1319).

b. Selain dari itu, yang dapat diketengahkan pula adalah bahwa dianutnya asas konsensualisme, yaitu dasar dari perjanjian yang memerlukan adanya kata sepakat di antara pihak pembuat perjanjian. Asas konsensualisme merupakan dasar dari para pihak untuk melaksanakan perjanjian, karena untuk terlaksananya suatu perjanjian diperlukan adanya kata sepakat. Adanya kata sepakat merupakan langkah awal sahnya suatu perjanjian yang kemudain diikuti syarat-syarat lain. Oleh undang-undang ditegaskan bahwa, perjanjian yang telah disepakati akan berlaku sebagai undang-undang bagi mereka yang membuatnya (Pasal 1338). 
Pasal 1320 KUHPerd. yang mensyaratkan sahnya suatu perjanjian, yaitu:

1) Kata sepakat dari mereka yang saling mengikatkan diri:

2) Kecakapan untuk membuat suatu perjanjian:

3) Menyangkut suatu hal tertentu;

4) Mengenai suatu sebab yang halal.

Keempat hal tersebut mutlak harus dipenuhi untuk dapat dilaksanakan suatu perjanjian yang sah.

a. Kebebasan berkontrak yang diberikan oleh Buku III KUHPer tentunya juga dibatasi oleh pasal-pasalnya. Suatu sebab yang diperjanjikan adalah terlarang, jika dilarang oleh undang-undang, bertentangan dengan hukum, kesusilaan, maupun, ketertiban umum (Pasal 1337).

b. Bedrijfsreglementerings Ordonantie 1934 (BRO 34) tentang Penyaluran Perusahaan.

c. Undang-Undang No.1 tahun 1967 tentang Penanaman Modal Asing.

d. Undang-Undang No.11 tahun 1970 tentang Perubahan dan Penambahan Undang-Undang No.1 tahun 1967 tentang Penanaman Modal Asing.

e. PP No. 1 tahun 1957 tanggal 19 Januari 1957 tentang Penyaluran Perusahaan-perusahaan.

f. Kepmennindag No.402/MPP/Kep/11/1997 tanggal 3 Nopember 1997 Ketentuan Perizinan Usaha Perwakilan Perusahaan Perdagangan Asing.

g. Kepmendag No.23/MPP/KEP/1/1998 tentang LembagaLembaga Usaha Perdagangan.

h. Kepmenperindag-RI No.159/MPP/Kep/4/1998 tentang Perubahan Keputusan Menteri Perindustrian dan Perdagangan No.23/MPP/Kep/1/1998 tentang LembagaLembaga Usaha Perdagangan.

i. Dst.

\section{Perjanjian Distributor}

\section{A. Perjanjian Distributor}

Pada prinsipnya perjanjian distributor di buat dalam bentuk perjanjian baku, perjanjian baku adalah bentuk perjanjian yang 
disetujui oleh para pihak, yang lazimnya telah berbentuk formulir perjanjian yang telah ditentukan oleh pihak pertama yaitu pihak prinsipal. Dengan demikian perjanjian yang diadakan merupakan perjanjian baku atau perjanjian standar. Perjanjian baku adalah perjanjian yang dibuat secara kolektif dalam bentuk formulir.

Istilah perjanjian baku sebenarnya merupakan terjemahan yang dialih bahasakan dari istilah yang dikenal di dalam bahasa Belanda yaitu Standaard Contract atau Standaard voorwaden. Dalam literatur mengenai istilah standaard contract belum terdapat keseragaman. Kepustakaan Jerman misalnya menggunakan istilah Standaarvertrag, Standaarkonditionen atau Algemeine Geschaft Berdingun. Literatur di inggris menyebutnya dengan istilah standar contract, standarized contract. Menurut Mariam menterjemahkan standar contract dengan istilah perjanjian baku. Baku diartikan sebagai patokan ukuran atau acuan. Perjanjian baku menurut Mariam Darus adalah perjanjian yang isinya telah dibakukan dan dituangkan dalam bentuk formulir yang lazim dibuat secara kolektif.

Beberapa ahli hukum mencoba memberikan definisi mengenai apa yang dimaksud dengan perjanjian baku. Menurut Hondius:

standaartvoorwarden zijn schrijftelijke koncept
bedingen welke zijn opqesteld om zonder
onderhandelingen omtrent hun inhoud opqenomen te
woorden in een gewoonlijk onbepaald aantal nog te
sluiten overeenskomten van bepaald aard.
(terjemahan tidak resminya perjanjian baku ialah
konsep janji-janji tertulis, dan lazimnya disusun tanpa
membicarakan isinya dan dituangkan dalam sejumlah
tak terbatas perjanjian yang sifatnya tertentu).

Dalam hal ini Hondius selanjutnya mengemukakan bahwa kadang-kadang ketentuan isi perjanjian tersebut tidak disusun oleh satu pihak melainkan disusun oleh suatu oraganisasi perusahaan atau perdagangan. Perjanjian baku juga meliputi kontrak-kontrak yang telah dibakukan yang disusun oleh notaris atau perjanjian yang berlaku dikalangan tertentu.

${ }^{10}$ Hondius, "Standaardvoorwaarden". diss. Leiden. 1978. hal 230 dst [sic]. dikutip leh Mariam Darus. 
Menurut Drooglever Fortuijn, dalam tulisannya "de overheid en de standaard contracten," WNPR 5067, 1970, seperti yang dikutip oleh Mariam Darus, mengatakan bahwa perjanjian baku adalah:

Contracten waarven een belangrijk deel van de inhoud word bepaald door een vast samenstel van contracts bedingen.

(terjemahan tidak resminya Perjanjian yang bagian isinya yang penting dituangkan dalam susunan janjijanji)."

Abdul Kadir Muhammad dalam bukunya Perjanjian Baku Dalam Praktek Perusahaan Perdagangan menyatakan bahwa perjanjian baku ialah perjanjian yang menjadi tolak ukur yang dipakai atau dipergunakan sebagai patokan atau pedoman bagi setiap konsumen yang mengadakan hubungan hukum dengan pengusaha yang dibakukan di dalam perjanjian. Perjanjian demikian ialah merupakan model rumusan dan ukuran yang selanjutnya dikatakan bahwa perjanjian baku ialah naskah perjanjian yang memuat syarat-syarat baku yang dibuat secara tertulis berupa akta otentik atau akta di bawah tangan. ${ }^{12}$

\section{B. Perkembangan Perjanjian Baku}

Perjanjian baku telah berkembang secara pesat dan dapat kita jumpai dalam berbagai kehidupan manusia, dari bentuk yang paling sederhana hingga bentuk yang kompleks. Perjanjian baku diadakan dengan maksud untuk mencapai tujuan efisiensi, kepastian dan lebih bersifat praktis meskipun kadang-kadang mengandung faktor negatif. karena dapat merugikan pihak lain yaitu pihak konsumen yang lemah. Dalam perjanjian baku maka konsumen dalam hal ini hanya mempunyai dua pilihan yaitu menerima atau menolak perjanjian yang disodorkan kepadanya, yang artinya tidak terjadi transaksi antara para pihak. Dalam bahasa Inggris perjanjian baku sering diungkapkan

11 Mariam Darus."Perlindungan Terhadap Konsumen dilihat dari Sudut Perjanjian Baku (Standar)". (makalah disampaikan pada Simposium "Aspek-aspek Hukum Perlindungan Konsumen", Badan Pembinaan Hukum Nasional, Jakarta. 16-18 Oktober 198(0). hal. 3

12 Abdulkadir Muhammad. "Perjanjian Baku Dalam Praktek Perusahaan Perdagangan”, cet. I. (Bandung: Citra Aditya Bakti, 1996). hal. 6. 
sebagai take it or leave it contract. Dalam hal ini faktor yang menyebabkan perkembangan perjanjian baku antara lain adalah:

a. Faktor hukum: perjanjian baku lazim dipergunakan di dalam praktek, yakni karena adanya prinsip kebebasan berkontrak dalam perjanjian dan sebagai upaya untuk menciptakan kepastian hukum bagi para pihak karena segala sesuatu persyaratan telah ditentukan dalam bentuk klausula-klausula perjanjian.

b. Faktor ekonomi, karena perjanjian baku dapat dikatakan bersifat lebih efisien, lebih ekonomis sebagai upaya untuk menghemat biaya, waktu dan tenaga.

c. Faktor perkembangan teknologi, juga dapat merupakan penyebab dilakukannya perjanjian dalam bentuk standar. yaitu perkembangan industri yang amat pesat dan semakin lancarnya arus transportasi dan komunikasi.

\section{Macam-Macam Perjanjian Baku}

Di dalam praktek dapat diidentifikasi mengenai berbagai macam perjanjian standar atau perjanjian baku, dan perjanjian baku tersebut umumnya dipergunakan oleh masyarakat, untuk memenuhi kebutuhan mereka dalam mengadakan transaksi bisnis. Macam-macam perjanjian baku tersebut antara lain yaitu: ${ }^{13}$

a. Perjanjian standar sepihak, yang lazim disebut pula dengan istilah adhesi kontrak, yaitu suatu perjajian baku yang isinya ditentukan oleh pihak yang lebih kuat kedudukannya atau kedudukan ekonominya lebih kuat dalam perjanjian tersebut. Dalam perjanjian demikian, lazim pembuat perjanjian atau pihak ekonomi yang kuat (pihak kreditur), lebih banyak menentukan kewajiban-kewajiban kepada pihak yag mengikatkan diri dalam perjanjian yang lazimnya merupakan pihak ekonomi lemah (pihak debitur). Klausula yang bersifat demikian dinamakan klausula eksonerasi atau exemption clause.

b. Perjanjian baku timbal balik, yakni perjanjian standar yang isinya ditentukan oleh kedua belah pihak yang mengadakan perjanjian, misalnya perjanjian perburuhan yang diadakan

1) Theodorik Simorangkir." Masalah Hukum Dalam Perjanjian Baku (Suatu Tinjauan sormatif Perlindungan Konsumen)". (Skripsi FHUI. 1988), hal 55-57. 
oleh serikat buruh dan serikat majikan, yang merupakan perjanjian buruh kolektip atau perjanjian perburuhan. yang lazim dijadikan dasar bagi perjanjian kerja antara buruh dan majikan.

c. Perjanjian standar yang dibuat oleh pemerintah, yaitu perjanjian baku yag isinya ditentukan oleh pemerintah di dalam melakukan ikatan atau di dalam melakukan perjanjian dengan pihak lain. Misalnya perjanjian yang obyeknya hakhak atas tanah, perjanjian pemborongan perjanjian sewa beli rumah negeri, atau perjanjian-perjanjian lain dimana pemerintah ikut sebagai pihak di dalam perjanjian tersebut. dan sebagainya.

d. Perjanjian baku yang berlaku atau ditentukan bagi dikalangan tertentu, misalnya perjanjian yang dilakukan atau berlaku dikalangan notaris, pengacara, yaitu perjanjian yang sejak semula konsepnya telah disediakan untuk memenuhi permintaan anggota masyarakat yang meminta bantuan kepada notaris atau pengacara. Perjanjian baku demikian dikenal dengan contract model.

\section{Ciri-ciri Perjanjian Negatif Baku}

Di dalam praktek sehari-hari perjanjian standar yang sering dipergunakan ialah perjanjian standar atau perjanjian baku sepihak. yaitu perjanjian yang isinya ditentukan oleh salah satu pihak yanng lebih kuat kedudukan ekonominya, yang lazim disebut dengan adhesi kontrak. Mariam Darus Badrulzaman mempergunakan perjanjian sepihak untuk adhesi kontrak. Perjanjian baku sepihak tersebut di dalam prakteknya dibuat sedemikian rupa dengan berbagai versi dari bentuk standar yang sangat sederhana, sampai bentuk standar yang sangat kompleks dan panjang dengan klausula yang diketik dalam huruf yang sangat kecil, sehingga sulit dibaca. Oleh karena itu Drion mengemukakan bahwa di dalam adhesi terdapat 3 aspek yang merupakan ciri negatip perjanjian tersebut, yaitu bahwa:

a. perjanjian baku sepihak menempatkan kedudukan yang terjepit bagi pihak yang ikut serta atau pihak yang akan mengikatkan diri di dalam perjanjian tersebut. oleh karena itu adhesi kontrak lazim pula disebut dengan take it or leave it contract:

b. perjanjian baku sepihak pembuatannya dilakukan oleh salah satu pihak di dalam perjanjian, yaitu pihak yang mempunyai 
ekonomi kuat, sehingga kurang mengikut sertakan pihak lain, atau kurang memperhatikan kepentingan pihak lain yang akan mengikat diri;

c. Perjanjian baku sepihak isinya tidak diketahui oleh pihak yang akan mengikatkan diri, karena lazimnya perjanjian demikian telah ditentukan secara sepihak dan diketik dengan huruf ketik yang kecil, yang sulit dibaca dan ditempatkan pada bagian belakang perjanjian atau formulir yang disediakan.

\section{E. Berlakunya Perjanjian Baku}

Berlakunya perjanjian baku agar mengikat pihak lain, menurut Hondius terdapat 4 cara atau kemungkinan untuk memberlakukan syarat-syarat baku yang terdapat di dalam perjanjian yang lazimnya telah dipersiapkan terlebih dahulu, yaitu: ${ }^{14}$

a. Penandatanganan dokumen perjanjian. Dalam hal ini klausula-klausula perjanjian tersebut telah ditentukan terlebih dahulu dalam suatu formulir, ketika membuat perjanjian atau pihak ketiga akan mengikatkan diri maka dokumen atau formulir tersebut disodorkan kepada pihak yang akan mengikatkan diri untuk dibaca dan ditanda tagani. Dengan penandatanganan dokumen perjanjian tersebut maka pihak yag mengikat diri dalam perjanjian terikat pada syaratsyarat baku yang telah ditentukan sebagai klausula di dalam perjanjian tersebut;

b. Dengan pemberitahuan melalui dokumen perjanjian. Dalam hal ini menurut kebiasaan yang berlaku, maka syarat-syarat yang telah dibakukan dicetak di atas dokumen perjanjian yang tidak ditanda tangani oleh pihak yang akan mengikatkan diri, misalnya konosemen, surat angkutan, surat pesanan, nota pembelian. Agar pihak lain terikat dalam perjanjian tersebut, maka dokumen perjanjian tersebut harus diterimakan atau dikirimkan kepada pihak yang mengikat diri di dalam perjanjian tersebut, pada saat atau sesudah dibuatnya perjanjian tersebut;

c. Dengan penunjukkan dalam dokumen perjanjian. Dalam dokumen perjanjian tidak dimuat syarat-syarat baku, tetapi

${ }^{14}$ E.H Hondius, Op. Cit.. hal. 143. 
dalam dokumen perjanjian tersebut hanya menunjuk kepada syarat-syarat baku tertentu, misalnya di dalam dokumen perjanjian jual beli perdagangan ditunjuk syarat penyerahan barang atas dasar FOB atau CIF. Dalam hal ini maka diartikan bahwa mengenai syarat penyerahan barang atas dasar FOB (Free On Board) atau CIF (Cost Insurance Freight) berlaku terhadap perjanjian yang diadakan oleh para pihak tersebut;

d. Pemberitahuan melalui papan pengumuman. Dalam hal ini syarat-syarat baku yang ditentukan dapat merupakan bagian dari isi perjanjian dengan cara pemberitahuan melalaui papan pengumuman. Cara demikian lazim digunakan oleh perusahaan yang bergerak dalam bidang pelayanan umum yang melayani banyak orang atau masyarakat umum dalam waktu yang bersamaan.

\section{F. Ciri-Ciri Karakteristika Perjanjian Baku}

Berdasarkan uraian tersebut di atas, maka kiranya dapat di identifikasi ciri-ciri karakteristik suatu perjanjian standar atau perjanjian baku, antara lain ialah:

a. isinya lazimnya ditentukan secara sepihak oleh pelaku usaha yang mempunyai kedudukan atau posisi ekonominya lebih kuat;

b. masyarakat yang mengikatkan diri dalam perjanjian atau pihak konsumen tidak ikut terlibat dalam menentukan isi perjanjian;

c. terdorong oleh kebutuhan tertentu, konsumen terpaksa harus menerima perjanjian itu. artinya mau tidak mau konsumen harus mengikuti ketentuan perjanjian tersebut, jika akan mengikatkan diri dengan pengusaha;

d. perjanjian itu dipersiapkan terlebih dahulu dalam jumlah banyak (massal) atau bersifat kolektif;

e. isi perjanjian terdiri dari rangkuman janji-janji yang merupakan syarat-syarat perjanjian, atau klausula-klausula perjanjian seperti misalnya mengenai cara mengakhiri perjanjian, cara memperpanjang masa berlakunya perjanjian. cara penyelesaian sengketa dan syarat-syarat atau klausulaklausula eksonerasi;

f. perjanjian standar lazimnya tidak dimungkinkan untuk dirubah; 
g. bentuknya tertentu (tertulis); dan

h. perjanjian baku pada umumnya menguntungkan pihak pelaku usaha atau kreditur.

\section{G. Syarat dan Prosedur Perijinan}

Suatu perusahaan nasional yang ingin memperoleh pengakuan keagenan/distributor diwajibkan untuk mengajukan permohonan tertulis kepada departemen perindustrian dan perdagangan dengan melampirkan akta pendirian perusahaan, angka pengenal impor (A.P.I), akta perjanjian yang dilakukan dengan pihak prinsipal antara prinsipal dengan distributor serta bukti pemilikan akta rencana pengadaan fasilitas keagenan/distributor.

Syarat-syarat yang harus dipenuhi sebagai agen/distributor dari barang-barang produk luar negeri antara lain adalah: ${ }^{15}$

a. Surat Izin Usaha Perdagangan (SIUP).

b. Akta pendirian dan perubahan perusahaan.

c. Surat penunjukan dari produsen kepada distributor, apabila penunjukkan itu dilakukan terhadap perusahaan distributor.

d. Surat perjanjian selaku agen/distributor yang sudah dilegalisir oleh notaris.

e. Surat pernyataan yang menyebutkan bahwa terhadap barang tersebut belum ada perusahaan yang ditunjuk sebagai agen/distributor.

f. Leaflet/brosur/katalog asli dari barang dan jasa yang diageni/distributor dan dari brosur/katalog itu akan dapat dilihat data mengenai barang dan perusahaan prinsipal serta perwakilan-perwakilan di negara lainsecara jelas.

g. Barang yang diageni itu buka termasuk barang yang dilarang untuk diimpor.

Dalam kaitan dengan masalah perizinan maka lazimnya diperlukan persyaratan yang mengacu kepada lima aspek yaitu:

a. Syarat untuk mendapatkan izin.

b. Bobot kegiatan usaha yang dikaitkan dengan izin yang diberikan.

15 Laporan Pengkajian tentang Beberapa Aspek Hukum Perjanjian Keagenan dan Distribusi yang disusun oleh Badan Pembinaan Hukum Nasional Departemen Kehakiman tahun 1992/1993, hal. 26. 
c. Berbagai syarat penopangnya yang terkait dengan dampak pemberian izin yang bersangkutan.

d. Berbagai hak dan manfaat yang dapat digunakan oleh penerima izin.

Penerima izin diharuskan untuk memenuhi kewajiban sesuai dengan pengarahan pemerintah.

\section{Implementasi Umum Kontrak Distributor dalam Praktek}

Perjanjian Baku adalah bentuk perjanjian yang disetujui oleh para pihak dalam bentuk tertulis berupa formulir perjanjian yang telah ditentukan oleh pihak pertama yaitu pihak prinsipal, dimana dengan demikian kontrak yang diadakan merupakan perjanjian baku atau perjanjian standar. Perjanjian baku adalah perjanjian yang dibuat secara kolektif dalam bentuk formulir. Pernyataan ini sejalan dengan memperhatikan fakta dari format kontrak yang telah ditandatangani oleh para pihak tersebut di atas secara awam dapat diketahui terdapat beberapa bagian yang memang sengaja dikosongkan sebagai reservasi apabila ternyata terdapat perbedaan antara kontrak distributor yang satu dengan kontrak yang lainnya. Adapun bagian-bagian yang sengaja dikosongkan antara lain adalah:

1. Kolom para pihak, khususnya kolom distributor;

2. Kolom Territory;

3. Kolom yang berkenaan dengan masa berlaku perjanjian dan ketentuan-ketentuan lain yang mengatur mengenai pembatasan jangka waktu (baik dalam hitungan hari, bulan maupun tahun):

4. Kolom Agen (dalam hal ini adalah agen pembayaran dalam transaksi ini yang setiap saat dapat berubah);

5. Kolom harga objek yang didistribusikan.

6. dst.

Identifikasi dapat dilakukan secara mudah dan cepat, dimana pihak prinsipal dalam hal ini telah terlebih dahulu memberikan kolom-kolom yang siap diisi setiap saat dengan menggantungkan diri pada pihak distributor. besaran nilai transaksi, dan hal-hal lain yang merupakan kewajiban dari pihak distributor yang perlu dijadikan sebagai bahan pertimbangan oleh prinsipal. Namun di lain pihak selain ditentukan lain oleh para pihak (khususnya oleh prinsipal) tidak terdapat suatu penambahan dan/atau perubahan yang sifatnya spesifik atau setidaknya terjadi penambahan atau perubahan, dan dapat dengan mudah diidentifikasi oleh penulis. 
Berdasarkan hal tersebut di atas, maka seharusnya dengan adanya azas kebebasan berkontrak tersebut, posisi kedua belah pihak adalah sama dan sederajat. Namun, dalam praktek sehari-hari kita bisa melihat bahwa sebenarnya kedua pihak tidak dalam posisi yang seimbang. Seringkali terjadi pihak distributor harus menerima persyaratan-persyaratan yang diberikan oleh perusahaan produsen secara mutlak tanpa bisa menawar lagi. Hal ini disebabkan perusahaan prinsipal telah mempersiapkan standar formulirformulir kontrak, berarti bagi distributor yang ingin mengadakan perjanjian dengan pihak produsen terikat dengan formulir-formulir kontrak yang sudah disediakan pihak produsen. Adapun hal yang melatarbelakangi dibuatnya suatu standar kontrak adalah untuk mempermudah perusahaan prinsipal dalam menjalankan usahanya, yang dalam lingkup usahanya perusahaan prinsipal telah mempersiapkan jaringan distribusi produknya tidak secara ekslusif dipegang oleh 1 (satu) distributor dan hanya pada 1 (satu) negara, melainkan lebih dari itu. Oleh karenanya untuk mempermudah aspek pemahaman transaksi, pola administrasi dan permasalahan lainnya, maka perusahaan prinsipal cenderung menjalankan pola pemberlakuan standar kontrak baku tersebut.

Perjanjian baku diadakan dengan maksud untuk mencapai tujuan efisiensi, kepastian dan lebih bersifat praktis meskipun kadang-kadang mengandung faktor negatif, karena dapat merugikan pihak lain yaitu pihak konsumen yang lemah. Dalam perjanjian baku maka konsumen dalam hal ini hanya mempunyai dua pilihan yaitu menerima atau menolak perjanjian yang disodorkan kepadanya, yang artinya tidak terjadi transaksi antara para pihak. Dalam bahasa Inggris perjanjian baku sering diungkapkan sebagai take it or leave it contract. Ada hal yang perlu digaris bawahi oleh penulis dalam menyikapi perjanjian baku ini adalah undang-undang tidak melarang siapapun juga untuk membuat, memasuki, menandatangani dan/atau menjadi pihak dalam suatu kontrak dimaksud, sepanjang kontrak baku tersebut tidak memuat hal-hal yang secara tegas-tegas dilarang oleh undang-undang, yaitu perjanjian dibuat dengan tidak melanggar ketertiban umum dan kesusilaan, dimana oleh karenanya perjanjian yang telah dibuat oleh para pihak tersebut berlaku sebagai undang-undang bagi mereka yang membuatnya.

Pada umumnya kontrak yang dilakukan oleh dan antara prinsipal dengan distributornya, yang lazim terjadi isinya ditentukan oleh pihak yang lebih kuat kedudukannya atau kedudukan ekonominya lebih kuat dalam perjanjian tersebut. Dalam perjanjian demikian, lazim pembuat perjanjian atau pihak ekonomi yang kuat (pihak kreditur), lebih banyak menentukan kewajiban-kewajiban kepada pihak yang mengikatkan diri dalam perjanjian yang lazimnya merupakan pihak ekonomi lemah (pihak distributor). Klausula 
yang bersifat demikian dinamakan klausula eksonerasi atau exemption clause.

Hal mana sebenarnya tidak semata-mata dikarenakan pihak tersebut secara ekonomi lebih kuat, yang sebenarnya faktor tersebut memang juga tidak dapat dipungkiri, tetapi apabila dilihat dari perspektif pihak prinsipal maka sudah barang tentu yang menjadi pemikiran adalah bagaimana pihaknya memperoleh reservasi dan/atau pihak terjamin untuk memasuki sebuah transaksi. Sebagaimana kendala yang mungkin timbul adalah prinsipal yang merupakan perusahaan yang tergolong dalam lingkup lembaga wholesaler, prinsipal beranggapan bahwa perusahaannya merupakan salah satu perusahaan yang bonafid dan memiliki jaringan pemasaran yang luas dan tersebar diseluruh penjuru dunia, dimana apabila masing-masing negara yang bersedia untuk mengadakan kerjasama distribusi memberikan draft perjanjiannya secara tersendiri, maka sudah barang tentu akan terjadi suatu kesulitan dalam pemahaman transaksi. Terlebih lagi terhadap permasalahan perbedaan sistem hukum, atau meskipun menggunakan sistem hukum yang sama tetapi sudah barang tentu kinerja dari sistem hukum yang sama tersebut antara satu negara dengan negara lainnya berbeda, yang dikarenakan oleh faktor sosiologis dan antropologis suatu masyarakat serta seberapa dekat masyarakat tersebut dekat dengan perkembangan dan globalisasi dibidang tekonologi.

Apabila ditarik mundur sejarah menunjukan tentang latar belakang sistem hukum Belanda yang kemudian berlaku di Indonesia, yang mana salah satu alasan mendasarnya adalah pihak kolonial Belanda dalam mengadakan transaksi jual beli rempah-rempah dengan berbagai macam suku bangsa yang berbeda di Hindia Belanda, mengalami kesulitan dikarenakan pengetahuan mereka yang sangat minim tentang hukum adat yang berlaku pada masingmasing suku. Sementara itu dilain pihak kolonial Belanda tetap memerlukan rempah-rempah yang merupakan hasil bumi Hindia Belanda, maka untuk mempermudah jalannya transaksi pola yang diterapkan dan diberlakukan dalam transaksi jual beli dimaksud adalah dengan menggunakan hukum Belanda, dimana pada satu pihak para kolonial Belanda lebih mengetahui hukum mereka dan di lain pihak tercipta suatu efisiensi, serta dikarenakan alasan-alasan lainnya. Seiring dengan perkembangan yang terjadi dan dengan terjadinya dominasi kolonial Belanda, maka masyarakat Hindia Belanda menjadi terpengaruh dan melihat bahwa perlu diadakan suatu kerangka hukum yang konstruktif agar tercipta efisiensi dan efektifitas dalam kehidupan sosial kemasyarakatan. Sehingga sampai sekarang sistem tersebut tetap berlaku namun banyak pihak yang berupaya untuk melakukan perubahan terhadap sistem hukum peninggalan kolonial Belanda dimaksud. 
Sejarah menunjukan tentang faktor kekuatan ekonomi, faktor efisiensi dan efektifitas serta faktor-faktor lainnya yang mempengaruhi penilaian masyarakat dan dalam rangka menunjang untuk terjadinya suatu proses penciptaan atau setidaknya pemahaman/penyamaan perspektif dalam menyikapi suatu sistem hukum atau perjanjian. Sehingga tercipta suatu fleksibilitas antara keinginan dari para pihak yang memasuki dan menandantangani kontrak, termasuk dan tidak terbatas pada kontrak distributor dimaksud.

Jika diperhatikan lebih mendalam hal melatarbelakangi disepakatinya kontrak distributor adalah kepentingan dari para pihak yang perlu untuk dijembatani. Prinsipal dalam sudah barang tentu bertindak dan/atau bersifat untuk memproduksi barang-barang, yang dilain pihak memiliki suatu kendala dalam memasarkan produk mereka, dimana asumsinya adalah pangsa pasarnya terbatas pada lingkup lokal dan sekitar dari domisili prinsipal. Tetapi dalam dunia bisnis tidaklah demikian, dimana agar perusahaan dapat memperoleh keuntungan yang lebih, maka diperlukan suatu perluasan jaringan pasar. Pertanyaannya adalah apakah prinsipal dapat melakukan hal semacam itu mengingat kemungkinan untuk terjadinya monopoli dan biaya yang dikeluarkan oleh pihak prinsipal justru membengkak apabila prinsipal harus membuka cabang-cabang divisi pemasarannya baik domestik maupun internasional. Begitu banyaknya prosedur yang harus ditempuh, terutama prosedur hukum yang sudah barang tentu negara yang satu berbeda dengan negara lainnya, maka mengakibatkan kompleksitas usahanya semakin rumit dan tidak tertutup kemungkinan biaya operasional usahanya menjadi membengkak. Oleh karenanya dalam perkembangan dunia perdagangan lahirlah lembaga-lembaga yang memiliki fungsi sebagai perpanjangan tangan dari prinsipal, yang seiring dengan perkembangan dikenal dengan istilah perusahaan penyaluran, agen, distributor dan sebagainya. Di lain pihak lembaga penyaluran ini ada tidak semata-mata terkungkung pada konteks keberadaannya yang diperlukan, tetapi juga dikarenakan adanya manfaat maupun keuntungan yang dapat diperoleh melalui kegiatan usaha penyaluran tersebut. Sehingga keberadaan kedua lembaga perdagangan tersebut sebenarnya menciptakan suatu sinergi perekonomian yang kondusif dan konstruktif. Namun demikian, perlu adanya suatu kerangka yang secara spesifik mengatur tentang hak dan kewajiban dari masing-masing pihak yang terlibat didalamnya. Kerangka tersebut berada dalam kerangka tatanan hukum, yaitu yang lazim dikenal dengan istilah kontrak.

Kontrak distributor pada umumnya tidak terdapat suatu format baku dan oleh karenanya tidak terdapat suatu bentuk keseragaman format, tetapi selayaknya sebuah kontrak. maka didalamnya diatur secara spesifik tentang segala sesuatu yang berkaitan dengan kepentingan para pihak. Dengan kata 
lain kontrak merupaka suatu sarana meeting of the minds among the parties thereto. Prinsip lain yang perlu diperhatikan dalam perjanjian baku adalah masalah pilihan. Para pihak dalam kontrak tersebut telah menjatuhkan pilihannya untuk saling mengikatkan diri. Suatu ikatan pada umumnya tidak akan dapat dilaksanakan apabila melulu dalam perjanjian tersebut sangat berat sebelah dan tidak memberikan keuntuangan/manfaat bagi pihak yang lainnya. Alasan untuk menciptakan iklim perekonomian yang baik memang merupakan konsep yang ideal, tetapi motivasi yang timbul adalah sebenarnya untuk memperoleh keuntungan finansial bagi perusahaan.Oleh karenanya meskipun perjanjian ini sifatnya baku tetapi secara finansial menguntungkan, maka sudah merupakan suatu hal yang logis apabila distributor memilih untuk mengikuti standar baku dimaksud.

\section{Penutup}

Lembaga Distributor adalah setiap individu/perseorangan, kemitraan, perusahaan, asosiasi atau hubungan hukum lainnya yang kedudukannya berada diantara produsen dan pedagang eceran dalam pembelian. pengiriman-pengiriman atau perjanjian penjualan barang-barang konsumsi. Pemborong dari sebuah Pedagang Besar atau pedagang perantara lainnya yang ditunjuk/diberikan wewenang oleh produsen atau leveransir untuk secara umum menjual kepada pedagang eceran atau pengguna komersial lainnya. Bentuk perjanjian yang diadakan oleh para pihak di dalam perjanjian kedistributoran termasuk dalam perjanjian innominat (tak bernama), yang tidak diatur secara khusus dalam KUHPer, tetapi keberadaannya dimungkinkan berdasarkan asas konsensualisme, dan tidak memuat hal-hal yang secara tegas-tegas dilarang oleh undang-undang, yaitu perjanjian dibuat dengan tidak melanggar ketertiban umum dan kesusilaan, dimana oleh karenanya perjanjian yang telah dibuat oleh para pihak tersebut berlaku sebagai undang-undang bagi mereka yang membuatnya.

Adapun dasar ketentuan yang mengatur kerangka umum keberadaan lembaga distributor adalah Pasal 1319 KUHPer, Pasal 1338 KUHPer, Pasal 1320 KUHPer, Pasal 1337 KUHPer, Bedrijfsreglementerings Ordonantie 1934 (BRO 34) tentang Penyaluran Perusahaan; Undang-Undang Nomor 11 tahun 1970 tentang Perubahan dan Tambahan Undang-undang No. 1 Tahun 1967 tentang Penanaman Modal Asing, PP No. I tahun 1957 tentang Penyaluran Perusahaan-perusahaan, Kepmennindag No. 402/MPP/Kep/11/1997 tentang Ketentuan Perizinan Usaha Perwakilan Perusahaan Perdagangan Asing, Kepmendag No. 23/MPP/KEP/1/1998 tentang Lembaga-Lembaga Usaha Perdagangan. Kepmenperindag-RI No. 
159/MPP/Kep/4/1998 tentang Perubahan Keputusan Menteri Perindustrian dan Perdagangan Nomor 23/MPP/Kep/1/1998 tentang Lembaga-Lembaga Usaha Perdagangan.

Perjanjian yang dibuat oleh dan antara prinsipal dengan distributornya kerapkali menggunakan format perjanjian baku yang dibuat secara kolektif dalam bentuk formulir. Akan tetapi di sisi lain masih memberikan suatu kelonggaran-kelonggaran, yang oleh karenanya kebakuan tersebut dipandang masih relevan dan logis untuk pihak distributor tunduk dan mengikatkan dirinya terhadap seluruh klausul yang ada didalamnya. Latar belakang dibuatnya suatu perjanjian baku adalah untuk mempermudah perusahaan prinsipal dalam menjalankan usahanya, yang dalam lingkup usahanya perusahaan prinsipal telah mempersiapkan jaringan distribusi produknya tidak secara ekslusif dipegang oleh 1 (satu) distributor dan hanya pada 1 (satu) negara, melainkan lebih dari itu. Oleh karenanya untuk mempermudah aspek pemahaman transaksi, pola administrasi dan permasalahan lainnya, maka perusahaan prinsipal cenderung menjalankan pola pemberlakuan standar perjanjian baku tersebut. 


\section{DAFTAR PUSTAKA}

Badan Pembinaan Hukum Nasional Departemen Kehakiman. Laporan Pengkajian tentang Beberapa Aspek Hukum Perjanjian Keagenan dan Distribusi tahun 1992/1993.

Badarulzaman. Mariam Darus. "Perlindungan Terhadap Konsumen dilihat dari Sudut Perjanjian Baku (Standar)", (makalah disampaikan pada Simposium "Aspek-aspek Hukum Perlindungan Konsumen", Badan Pembinaan Hukum Nasional. Jakarta, 16-18 Oktober 1980).

Black, Henry Campbell MA. Black's Law Dictionary, Abridged Sixth Edition, $8^{\text {th }}$ reprint -1998 (U.S. West Publishing Company), 1979.

Giplin, Alan. Dictionary Of Teras, London: ButterWorth \& Co. 1977.

Muhammad, Abdulkadir. Perjanjian Baku Dalam Praktek Perusahaan Perdagangan, cet. I. (Bandung: Citra Aditya Bakti, 1996).

Purwosutjipto, H.M.N. Pengertian Pokok Hukum Dagang I, (Jakarta. 1995).

Simorangkir, Theodorik. "Masalah Hukum Dalam Perjanjian Baku (Suatu Tinjauan Normatif Perlindungan Konsumen)", (Skripsi FHUI, 1988).

Soebagjo, Felix Oentoeng. "Beberapa Aspek Hukum Dari Perjanjian Keagenan Dan Distributor", Majalah Hukum dan Pembangunan. Tahun ke-27 No. 3 April-Juni, Jakarta: Fakultas Hukum Universitas Indonesia.

Susilo, P. Prinsip-prinsip Praktis Perlindungan Distributor, Jakarta. 2002. 